\title{
Crafting Youth Sentences: \\ The Roles of Rehabilitation, Proportionality, RESTRAINT, RESTORATIVE JUSTICE, AND RACE UNDER THE YOUTH CRIMINAL JUSTICE ACT
}

\section{SANJEEV ANAND}

The author examines the scope and direction of legislative guidance in assessing youth sentences under the Youth Criminal Justice Act It is contended that the Act does not support a reduction in otherwise proportional youth sentences on the basis of rehabilitative concerns. Proportionality of sentences is a primary concern. but considerations such as restraint, rehabilitation, and restorative justice may affect a sentence's conditions or form. The Youth Criminal Justice Act contains clear direction to limit the over-use of custody for youth. Aboriginal offenders are subject to a different methodology for determining sentences, with proportionality considered one of many concerns, rather than the principal one as it is for nonAboriginal offenders. The author suggests that the judiciary will determine whether the Act's provisions will succeed in altering youth sentencing patterns, and that those efforts may be hindered by a lack of alternatives if provincial and federal governments do not invest in non-custodial sentencing options.
L'auteur examine la portée et la direction de lorientation législative relativement aux peines accordées aux jeunes en vertu de la Loi sur le système de justice pénale pour les adolescents. On prélend que la Loi ne va pas dans le sens d'une réduction autrement proportionnelle du nombre de peines pour les jeunes sur la base de questions de réadaptation. La question de la proportionnalité de la peine représente une préoccupation fondamentale, mais les considérations relatives au confinement, da la réadaptation et la justice réparatrice peuvent avoir une incidence sur les conditions ou la forme de la peine. La Loi sur le système de justice pénale pour les adolescents contient des indications claires visant à limiter la sur-utilisation du placement sous garde des adolescents. Les délinquants autochtones font l'objet d'une méthodologie différente quand il s'agit de déterminer la peine, la proportionnalité étant uniquement un des aspects considérés alors qu'il s'agit du principal aspect considéré dans le cas de délinquants non autochtones. L'auteur suggère que le système judiciaire détermine si les dispositions de la Loi permettront de modifier les modèles de peine pour les adolescents et que ces efforts risquent de souffrir du manque de solutions de rechange si les gouvernements provinciaux ou fédéraux $n$ 'investissent pas dans les options de sentences sans placement sous garde.

\section{TABLE OF CONTENTS}

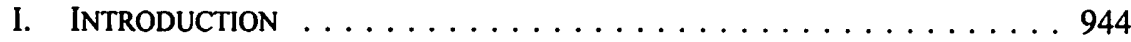

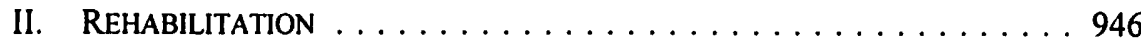

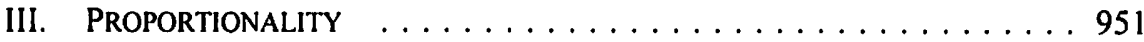

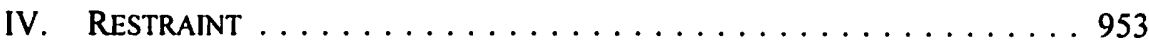

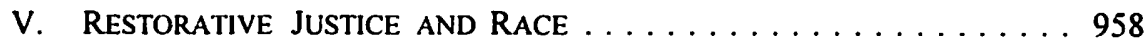

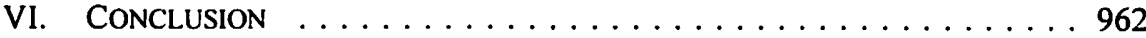

Associate Professor, Faculty of Law, University of Alberta. The author thanks Catherine McMaster for her tireless research assistance, Nicholette Anand for her invaluable editing, and Priya Anand for her patience during the writing process. Gratitude is also expressed to Virinder and Savinder Anand for helping the author meet the deadline for this article. 


\section{INTRODUCTION}

One of the great impetuses for repealing the Young Offenders Act and replacing it with new legislation is the dissatisfaction felt by many people concerning youth court sentencing. Indeed, polling results from the late 1990s have been cited as evidence of a widespread public belief that youth court sentences are too lenient. ${ }^{2}$

However, some individuals who have had an opportunity to closely examine the operation of the youth justice system attribute their disquiet about young offender sentencing to the harshness associated with the juvenile justice regime. A review of incarceration statistics demonstrates that youths are given custodial sentences at a rate four times higher than those given to adults. ${ }^{3}$ In fact, Canada could fairly be described as a world leader in imprisoning youth, with an incarceration rate twice that of the United States and ten to fifteen times that of many European countries, Australia, and New Zealand. ${ }^{4}$ Particularly troubling for many is the overrepresentation of Aboriginal young people in the youth correctional system. While Aboriginal young people constitute 5 percent of the youth population, they account for 24 percent of admissions to sentenced custody. ${ }^{5}$ Although for many offences young people sentenced in youth court are subject to potentially shorter maximum terms of imprisonment than adults, those youths who commit the most serious offences can be transferred to adult court. In addition, youths sentenced in youth court often serve longer sentences than adults sentenced in adult court because adults, unlike youths, are virtually automatically granted reductions in sentence for remission. ${ }^{6}$ Those who feel that sentencing under the YOA is too punitive in its effects can also point to the fact that in 2000-2001 only 27 percent of custodial sentences were imposed for violent offences and that most

Young Offenders Act, R.S.C. 1985, c. Y-1 [hereinafter YOA].

A.N. Doob \& J.B. Sprott, "Changes in Youth Sentencing in Canada" (1999) 2 Federal Sentencing Reporter 262 at 262.

Canada, House of Commons. Thirteenth Report of the Standing Committee on Justice and Legal Affairs: Renewing Youth Justice (Ottawa: Public Works and Government Services Canada, 1997) at 18 [hereinafter Renewing Youth Justice]. However, as Roberts points out, the juvenile incarceration rate includes both open and secure custody, with the former usually constituting a milder form of incarceration that is not, strictly speaking, accorded to adult offenders. See J.V. Roberts, "Juvenile Justice Reform in Canada" (1999) 2 Federal Sentencing Reporter 255 at 259. Section 24.1 of the $Y O A$ defines an open custody facility as a "community residential centre, group home, child care institution, or forest or wilderness camp, ... or any other like place or facility designated ... as a place of open custody." The same section defines secure custody as a place "for the secure containment or restraint of young persons."

Renewing Youth Justice, ibid. at 18.

J. Marinelli, "Youth Custody and Community Services in Canada, 2000-0I" (2002) 22:8 Juristat at 5 .

Young offenders, who are not subject to parole or mandatory supervised release, are instead subject to judicially controlled release by virtue of s. 28 of the YOA, and custodial sentences are not automatically reduced on judicial review. For example, in British Columbia the 1990 statistics indicate that young offenders committed to custody serve more than 80 percent of the original sentences imposed, whereas imprisoned adult offenders serve less then two-thirds of their sentences. Statistics Canada, Sentencing in Youth Courts (Ottawa: Canadian Centre for Justice Statistics. 1990) at 5 . 
admissions to custody were for property-related offences or administration of justicerelated offences.?

There are indications that a sizeable proportion of the public believe that the youth justice system should perform more than just a punitive function. When citizens from across the country were recently polled and asked what the best way was to combat juvenile crime, a majority of respondents indicated that preventive programs are the most effective deterrent against youth crime. ${ }^{8}$

The late 1990s was also a period when victims' rights groups became more active. Their lobbying has led to an increased recognition of the concerns of crime victims in the establishment and enforcement of criminal justice policy. Nevertheless, as pointed out in Kent Roach's article in this issue of the Alberta Law Review, victims of youth crimes do not necessarily desire the greater use of incarceration for young offenders. ${ }^{9}$ Some victims of crime look with favour to restorative justice approaches to provide them with reparation from offenders. ${ }^{10}$

A review of Parliament's new juvenile justice legislation, the Youth Criminal Justice $A c t,{ }^{11}$ reveals that Ottawa's approach is to include something for everyone who is dissatisfied with the current state of sentencing under the YOA. The general Declaration of Principle in the $Y C J A$ states that young people who commit offences should be encouraged to repair the harm done to victims and the community. ${ }^{12}$ The principles specific to sentencing contained within the new legislation assert the importance of rehabilitating young people who are subject to youth court sentences. ${ }^{13}$ The $Y C J A$ also

Marinelli, supra note 5 at 6 . Administration of justice offences include failure to comply with a disposition, such as a term of probation or a community service order, as well as offences such as failure to appear in court. Property offences accounted for more than 39 percent of sentenced admissions to custody for young offenders.

× C. Cobb, "Canadians against Police Crackdowns" Ottawa Citizen (12 March 2001) A3.

" Sec K. Roach, "The Role of Crime Victims Under the Youth Criminal Justice Act" in this issue at 965 .

11 Although it is difficult to provide an accurate and comprehensive definition for restorative justice, the one adopted by the Supreme Court of Canada in $R$. v. Proulx, [2000] I S.C.R. 61 at 80 [hereinafter Proulx] at least yields insight into how Canada's highest court views this approach:

Restorative justice is concerned with the restoration of the parties that are affected by the commission of an offence. Crime generally affects at least three parties: the victim, the community, and the offender. A restorative justice approach seeks to remedy the adverse effects of crime in a manner that addresses the needs of all parties involved. This is accomplished, in part, through the rehabilitation of the offender, reparations to the victim and to the community, and the promotion of a sense of responsibility in the offender and acknowledgment of the harm done to victims and to the community.

The theoretical underpinning of certain restorative justice processes and a description of some restorative justice programs, such as circle sentencing and family group conferencing, can be found in J. Braithwaite, Crime. Shame and Reintegration (Cambridge: Cambridge University, 1989) and T. Quigley, "Has the Role of Judges in Sentencing Changed ... or Should it?" (2000) 5 Can. Crim. L.R. 317 at 329-31. April 2003) [hereinafter $Y C J A$ ]. 
directs that alternatives to custody must be considered when imposing sentences, especially for Aboriginal young offenders. ${ }^{14}$ Yet the $Y C J A$ also recognizes proportionality as an important youth justice sentencing principle. ${ }^{\text {is }}$

The problem with including all of these sentencing principles within one statute is that they are potentially conflicting and inconsistent. Such legislative drafting could result in a lack of any significant structuring of judicial discretion in terms of crafting youth sentences.

Nevertheless, my examination of the provisions contained within the $Y C J A$ reveals that the collection of sentencing principles contained within it are actually prioritized and reconcilable. The YCJA does provide a great deal of legislative direction to youth justice court judges who are faced with the task of imposing youth sentences. In addition, if interpreted correctly, the YCJA may lead to a reduction in overall youth incarceration rates, a better correlation between the seriousness of a young person's offence and the punitiveness of a young person's penalty for committing an offence, a greater use of reparative/restorative sentences, and a more equitable use of rehabilitation in informing youth justice court sentencing decisions. Moreover, if the $Y C J A$ is interpreted by the judiciary in accordance with Parliament's intentions, many Aboriginal young people will be sentenced more leniently than non-Aboriginal young offenders who have committed similar offences in similar circumstances.

There are a number of topics that are beyond the scope of this article. Lawyers, academics, and judges who are interested in a detailed discussion of the new sentencing options under the $Y C J A$ will find that this article has little to offer them. ${ }^{16}$ In addition, this article does not address the complicated and controversial matter of when it is appropriate to impose adult sentences on young people under the $Y C J A .^{17}$

The primary objective of this article is to examine the extent and direction of legislative guidance in determining youth sentences under the $Y C J A$. In order to achieve this goal, specific provisions contained within the $Y C J A$ will be analyzed so that the roles of rehabilitation, proportionality, restraint, restorative justice, and race in fashioning youth sentences can be discerned.

\section{Rehabilitation}

Since at least 1908, rehabilitation has played an important role in the fashioning of sentences for young people who contravene the law. Under the Juvenile Delinquents $A c t,{ }^{18}$ rehabilitation was the engine that drove sentencing decisions. Regardless of the

See ibid., s. 38(2)(d).

See ibid., s. 38(2)(c).

For those interested in this important subject, 1 recommend N. Bala, Youth Criminal Justice Law (Toronto: Irwin Law, 2003) at 426-90.

17 For those intrigued by this topic, see Bala, ibid. at 500-52.

is Juvenile Delinquents Act, R.S.C. 1970, c. J-3 [hereinafter JDA]. The JDA was first assented to 20 July 1908, S.C. 1908. c. 40. 
impugned actions of the young person found to be a delinquent under the $J D A,{ }^{19}$ juvenile court judges were directed not to treat the young person as a criminal but "as one in a condition of delinquency and therefore requiring help and guidance and proper supervision." ${ }^{20}$ This "help" could consist of being detained in institutions for an indeterminate period of time while being given rehabilitative training, counselling, and treatment. A young person given such a sentence would be released when mental health officials concluded that rehabilitation had been achieved or the young person attained the age of 21 , whichever came first. ${ }^{21}$

The YOA is clearly more offence-oriented than the offender-oriented JDA. For instance, the maximum custodial sentences that can be imposed under the $Y O A$ are tied, in a general sense, to the type of offence committed by the young offender. ${ }^{22}$ However these maximum sentences do not provide much assistance to the judiciary in crafting specific sentences for particular young people who have contravened the law.

In 1993, the Supreme Court of Canada provided its first and only significant judgment regarding young offender sentencing principles under the YOA. In $R$. v. $M$.(J.J.), ${ }^{23}$ the court held that the ultimate aim of all youth sentences must be the reform and rehabilitation of the young people sentenced. In fact, the court seemed to endorse the imposition of disproportionately long sentences on youths on the basis of child-welfare concerns. The court also stated that general deterrence and proportionality have some role to play in fashioning young offender sentences, but that their importance is less in the youth sentencing context than the adult sentencing context. ${ }^{24}$

To be brought within the ambit of the JDA, young people did not have to commit Criminal Code offences. The $J D A$ provided for a single, all-encompassing offence of delinquency. Section $2(1)$ of the $J D A$ defined a "juvenile delinquent" as any child who 1) violated a provision of the Criminal Code; 2) violated a provincial statute or municipal by-law; or 3 ) was guilty of any "sexual immorality or any similar form of vice." In contrast, both the YOA and the YCJA limit their jurisdictions to those who have committed federal offences.

See JDA, ibid., s. 3(2).

lbid., s. 20.

For example, pursuant to s. $20(1)(k)(i)$ of the YOA, supra note 1, all offences, conviction for which must result in less than a maximum sentence of life imprisonment for an adult, yield a maximum term of imprisonment of two years for a young offender. Pursuant to s. 20(1)(k)(ii) of the YOA, with the exception of murder, all offences that could result in life imprisonment for an adult yield a maximum term of three years for a young offender. For youths found guilty of first degree murder in youth court, s. 20(1)(k.l)(i) states that the maximum youth court sentence is ten years. with a maximum of six years in custody and the balance on conditional supervision. Under $s$. $20(1)(k .1)($ ii), youths found guilty of second-degree murder in youth court face a maximum sentence of seven years, with a maximum custodial portion of four years and the balance on conditional supervision. For a more comprehensive discussion of the sentencing schemes under the YOA, see N. Bala, Young Offenders Law (Concord: Irwin Law, 1997) at 225-63.

R. v. M.(J.J.) (1993), 81 C.C.C. (3d) 487 (S.C.C.) [hereinafter M(J.J.)].

General deterrence aims, through the punishment imposed on one individual or group of individuals, to discourage other potential offenders from engaging in similar behaviour. The reason that general deterrence is not discussed as a principle of youth sentencing under the $Y C J A$ is that it appears that the drafters of the $Y C J A$ specifically excluded it. As a result, general deterrence is not a factor that can be considered by youth justice court judges in pronouncing sentences on young people. For further discussion of this point, see Bala, supra note 16 at $408-409$. Although the principle of proportionality has been expressed in various ways, a simple way of understanding what it represents is that the punishment should be proportionate in its severity to the gravity of 
Exactly how judges are to balance the principles of general deterrence, proportionality, and rehabilitation in any given case is a matter of largely unrestrained discretion. ${ }^{25}$

The Supreme Court of Canada's view of rehabilitation, in the context of young offender sentencing, has come under academic criticism. According to Nicholas Bala,

in the context of dealing with young offenders, many of whom have "troubled" family backgrounds, [M.(J.J.)] often means support for longer periods in a "controlled" environment, away from the presumed harmful influences of the family. This implicitly indicates support for longer custodial sentences for many young offenders. This is in direct contrast to the use of rehabilitation as a factor in adult sentencing, where it is invariably used to justify a shorter custodial sentence. From the point of view of the youth facing sentencing, the situation may seem unfair, since he may legitimately feel that he is being "punished" (i.e. receiving a longer sentence) because, in a case like [M.(J.J.)] ... his parents were alcoholics and abusive toward him. This will appear especially unfair if youths receive different sentences for the same offence because of differences in "family background". There is obviously a potential for unconscious class or racial bias to become a factor in the assessment of family backgrounds, and hence the length of sentence received. One can also ask why, if help is needed for a youth, it is not provided voluntarily or under the child protection legislation, in which case the focus of attention will be providing assistance, and questions of helping and punishing will not be confused. ${ }^{26}$

M.(J.J.)'s endorsement of using rehabilitation as a justification for imposing custodial sentences and/or making such sentences longer soon drew the attention of the federal government. In 1995, Parliament amended the YOA by adding a new provision to s. 24 . Prior to 1995 , s. 24(1) of the YOA stated,

The youth court shall not commit a young person to custody under paragraph $20(1)(\mathrm{k})$ unless the court considers a committal to custody to be necessary for the protection of society having regard to the seriousness of the offence and the circumstances of the young person.

In 1995, the following subsection was added to s. 24 :

(1.1) In making a determination under subsection (1), the youth court shall take into account: (a) that an order of custody shall not be used as a substitute for appropriate child protection, health and other social measures.

A literal interpretation of the opening phrase in s. 24(1.1) would lead one to conclude that a young person can no longer be given a custodial term on the basis of rehabilitation. However, the section does not explicitly state that if a youth court judge determines that a youth should receive a term of custody on a basis other than rehabilitation, that the sentence cannot be lengthened on the basis of rehabilitative

25

an individual's criminal conduct.

For evidence of the substantial disparity in youth court sentencing both pre- and post-M.(J.J.), see S.S. Anand, "Sentencing, Judicial Discretion and Juvenile Justice, Part I" (1999) 41 Crim. L.Q. 318 at $328-32,340-43$.

26 N. Bala, "R. v. M.(J.J.): The Rehabilitative Ideal for Young Offenders - Back to the Past?" (1993) 20 C.R. (4th) 308 at 309. 
concerns. Indeed, there is evidence that at least some courts have been sentencing in this manner since the enactment of s. 24(1.1)(a) of the YOA. ${ }^{27}$

Certain provisions in the YCJA make clear that youth justice court judges will no longer be able to impose custodial sentences on the basis of rehabilitation, nor will they be able to make custodial sentences, imposed for other reasons, longer on the basis of rehabilitation. Section 39(5) of the $Y C J A$ states that a "youth justice court shall not use custody as a substitute for appropriate child protection, mental health or other social measures." Consequently, unlike s. 24(1.1)(a) of the $Y O A$, the use of custody as a social measure in s. 39(5) is not linked by any express legislative language solely to the decision of whether or not to impose a custodial sentence. Furthermore, any ambiguity that still surrounds the meaning of s. 39(5) is resolved by an examination of the text of ss. $3(1)(c)$ (iii) and $38(2)(e)($ ii):

3.(1) The following principles apply in this Act:

(c) within the limits of fair and proportionate accountability, the measures taken against young people who commit offences should

(iii) be meaningful for the individual young person given his or her needs and level of development and, where appropriate, involve the parents, the extended family, the community and social or other agencies in the young person's rehabilitation and reintegration,

38.(2) A youth justice court that imposes a youth sentence on a young person shall determine the sentence in accordance with the principles set out in section 3 and the following principles:

(e) subject to paragraph (c) [which states that the sentence must be proportionate to the seriousness of the offence and the degree of responsibility of the young person for that offence], the sentence must

(ii) be the one that is most likely to rehabilitate the young person and reintegrate him or her into society[.]

Thus, it is clear that a youth justice court judge cannot, on the basis of rehabilitative concerns, impose a custodial sentence on a young person that is disproportionately long.

But can a young person's prospects of rehabilitation serve to reduce the length of a proportional custodial sentence or convert a proportional custodial sentence into a nonproportional non-custodial sentence? In other words, is there a rehabilitative discount for youth sentencing under the $Y C J A$ ? Bala thinks so. In his book on the $Y C J A$, he states, 
In summary, sections 3 and 38 require the court to begin the sentencing process by considering accountability and proportionality.... The court should then determine whether there are rehabilitative concerns and services available that would justify changing the nature and mitigating the severity of a sentence that would otherwise be imposed. ${ }^{28}$

Bala's perspective is eminently reasonable given the long-standing nature of the debate concerning the relationship between rehabilitation and proportionality. A number of academics assert that proportionality should serve merely as a brake on sentencing and not as the engine that drives the determination of sentence. ${ }^{29}$ Yet other noted scholars reject the notion that proportionality should only be used to inhibit excessive severity in sentencing. ${ }^{30}$

The Supreme Court of Canada recently resolved the issue of whether rehabilitative concerns could reduce the severity of otherwise proportional sentences for nonAboriginal adults sentenced under the Criminal Code. In Proulx, the court seems to endorse the view that the punitive value associated with proportional sentences should not be reduced by rehabilitative concerns. ${ }^{31}$

Proulx does not mean that rehabilitative principles have no place to play in the sentencing of non-Aboriginal adult offenders. In this case, the Supreme Court recognized that conditional sentences, which are terms of imprisonment of less than two years' duration that are served in the community on conditions, can and should usually include punitive conditions that are restrictive of the offender's liberty, such as house arrest or strict curfews. ${ }^{32}$ The Court acknowledged that a sentence of imprisonment is more punitive than the same period served as a conditional sentence. Consequently, proportionality, which demands a correlation between the gravity of an offender's offence and the punitiveness of the sentence imposed, can be satisfied in many cases by either a short- or medium-range custodial term or a long conditional sentence. For those offenders who have great rehabilitative potential, particularly if they can access certain programs in the community, the rehabilitative concerns associated with the

Supra note 16 at $411-12$.

For a philosophical defence of this position that is not tied to a particular legislative regime, see N. Morris, The Future of Imprisonment (Chicago: University of Chicago Press, 1974) at 73-77. For arguments that s. 718.1 of the Criminal Code, R.S.C. 1985, c. C-46 [hereinafter Criminal Code], which is preceded by the heading "Fundamental Principle" and whose text reads "A sentence must be proportionate to the gravity of the offence and the degree of responsibility of the offender," merely serves as a constraint when determining the question of how much punishment should be imposed on adults, see A. Manson, "A Brief Reply to Professors Roberts and von Hirsch" (1998) 10 C.R. (5th) 232.

30 For a philosophical defence of this position that is not tied to a particular legislative regime, see A. von Hirsch, "Proportionality in the Philosophy of Punishment" in M. Tonry, ed., Crime and Justice: A Review of Research (Chicago: University of Chicago Press, 1992) 55 at 75-76, 89-90. For arguments that s. 718.1 of the Criminal Code makes proportionality the engine driving sentencing and does not simply provide a limiting factor in formulating appropriate sentences for adult offenders, see J.V. Roberts \& A. von Hirsch, "Conditional Sentences of Imprisonment and the Fundamental Principle of Proportionality in Sentencing" (1998) 10 C.R. (5th) 222.

32 Proulx, supra note 10 at $88-89$. 
offender may influence the form a proportional sentence may take. Yet these concerns cannot reduce the punitiveness of that sentence. In regard to those offenders who have some, albeit limited, rehabilitative prospects, a court may decline to order what would constitute a long but proportional conditional sentence and instead impose a shorter yet proportional custodial term of imprisonment. But pursuant to s. 718(d) of the Criminal Code, one of the objectives of adult sentencing is to assist with the rehabilitation of offenders. Thus, rehabilitative services should be offered to adults while they are serving sentences of imprisonment.

The fact that rehabilitative concerns cannot trump proportionality when sentencing adult offenders does not necessarily mean that this will be the case in determining youth sentences under the $Y C J A$. However, there are provisions that the judiciary can rely on to support the conclusion that the $Y C J A$ does not contemplate a rehabilitative discount for otherwise proportional youth sentences.

\section{Proportionality}

The wording of s. $38(2)(\mathrm{e})$ of the $Y C J A$, which recognizes the principles of restraint, rehabilitation, and restorative justice, also states that any sentence fashioned using these principles is subject to the principle of proportionality. The ambiguity that surrounds this section pertains to the interpretation of the words "subject to." In the past, I have argued that this phrase leads inexorably to the conclusion that sentences are to be determined by the principle of proportionality, and that the other recognized principles merely affect the conditions under which young people must serve their proportionate sentences or the services they are offered while they are serving their proportionate sentences. ${ }^{33}$ Nevertheless, it can be contended that the wording of s. $38(2)(\mathrm{e})$ means that the other sentencing principles can inform the youth sentencing process so that the severity of an otherwise proportional sentence is reduced. But the other sentencing principles cannot make a sentence more punitive than the principle of proportionality dictates. Although I concede that the drafting of s. $38(2)(\mathrm{e})$ does not necessarily lead to the interpretation that I have previously advocated, I still believe that this interpretation is correct for the provision.

The principal reason why sentencing severity should not be allowed to be disproportionately lenient pertains to the principle of parity of treatment. Section $38(2)$ (b) of the YCJA requires that the sentence imposed on a young person is to be similar to the sentence imposed on other young persons "in the region" who have been found guilty of the same offence committed in similar circumstances. It is only when sentences are determined, and not merely limited, by the principle of proportionality that parity of treatment becomes an attainable objective. As Brodeur and Roberts observe,

If offenders have been convicted of crimes of comparable seriousness, they merit sentences of commensurate severity. Violation of this principle would make it impossible to maintain ordinal 
proportionality. Of course, this still leaves room for variability within an offence category; co-accused convicted of break and enter may not deserve sentences of comparable severity if their respective levels of culpability or blameworthiness are discrepant. ${ }^{34}$

Moreover, a proportionally-driven scheme of sentencing is not necessarily inconsistent with notions of restraint in the use of incarceration. ${ }^{35}$ In fact, there is evidence that some jurisdictions that have adopted proportionally-driven sentencing schemes have also greatly reduced their reliance on incarceration. ${ }^{36}$ Similar results have been reported by jurisdictions that have adopted fully proportional sentencing legislation for juvenile offenders. ${ }^{37}$

There are two ways to reduce the use of incarceration in a system that determines youth sentences in accordance with the principle of proportionality. The first is if youth justice court judges take seriously one of the key messages of Proulx: that long community-based sentences with punitive elements need to be increasingly used instead of onerously equivalent short custodial sentences. The second involves those offences whose seriousness demands punitive responses that cannot be accommodated within sentences served in the community. The length of the custodial sentences that would previously have been imposed for such offences should now be reduced on an acrossthe-board basis. However, it is important that this reduction in cardinal proportionality be accomplished while maintaining ordinal proportionality. ${ }^{38}$

The provisions in the $Y C J A$ go beyond indicating that proportionality is to be the guiding principle of youth sentencing. Particular portions of the $Y C J A$ also shed light on how judges are to assess the relative seriousness of offences for sentencing purposes. For instance, s. 38(3) states a number of factors that must be considered by youth justice court judges in determining a youth sentence. How judges are to take into account some of the factors listed, such as the degree of participation by the young person in the commission of the offence, and the harm done to victims, and whether

J.-P. Brodeur \& J.V. Roberts, "Taking Justice Seriously" (2001) 7 Can. Crim L.R. 77 at 82.

A youth sentencing scheme in which sentence severity is determined, and not simply limited, on the basis of proportionality does not have to result in barriers being erected to the achievement of rehabilitative objectives. This was illustrated in the previous discussion regarding the use of rehabilitation in adult sentencing. Proportionally-driven youth sentencing also does not automatically mean the rejection of restorative justice processes. This will be discussed in more depth later in the article.

u

See the evidence cited in Brodeur \& Roberts, supra note 34 at 80.

See, e.g., the reduction in overall incarceration rates and sentence lengths experienced by youths under Washington State's Juvenile Justice Act, Wash. Rev. Code Ann., s. 13.40 (West 1984). This phenomenon is described and analyzed in A. Schneider \& D. Schramm, "The Washington State Juvenile Justice System Reform: A Review of Findings" (1986) 1 Crim. Just. Pol'y Rev. 211. by adult offenders, constitute a reduction of cardinal proportionality from benchmark adult sentences. Section 3(1)(b)(ii) of the $Y C J A$, which states that the criminal justice system for young persons must be separate from that of adults and emphasize fair and proportionate accountability that is consistent with the greater dependency of young persons and their reduced level of maturity, provides an express explanation of why a reduction in cardinal proportionality from benchmark adult sentences is appropriate for young people who are given youth sentences. Nonetheless, the real challenge is for youth justice court judges to effect a reduction in cardinal proportionality from benchmark youth sentences imposed under the YOA. 
it was intentional or reasonably foreseeable, are fairly self-evident in a proportional sentencing process. Nonetheless, care should be taken to ensure that some of the other factors are interpreted consistently with the imposition of proportionate sentencing. For example, s. 38(3)(e) states that youth justice court judges must consider the previous findings of guilt of the young person. This subsection should not be used as a basis to give a young person who has committed a criminal offence, and who has previous findings of guilt, a more punitive sentence than a young person who has committed a similar offence in similar circumstances but who does not have any previous findings of guilt. ${ }^{39}$ The severity of sentences given in the two situations must be similar in order to ensure that the principles of proportionality and parity are respected. However, a criminal record can be used to guide the youth justice court judge's decision of the form of proportional sentence that should be given. For instance, the young person who has a criminal record consisting of many breaches of probation may be judged to be a good candidate for a short custodial sentence. ${ }^{40}$ The criminal record may indicate that the young person presents a significant risk for not complying with sentences served in the community. But the young person who has committed a similar offence in similar circumstances and does not have a criminal record may legitimately be judged a good candidate for a longer non-custodial sentence with punitive conditions. In the latter case, there may not be any evidence to suggest that the young person presents a risk of non-compliance with sentences directed to be served in the community.

\section{RESTRAINT}

Reducing the use of incarceration for young people who commit offences has been an objective of the federal government for quite some time. Yet despite Ottawa's efforts, its legislative action has had little or no effect.

The first real attempt to impose restrictions on youth custody under the $Y O A$ occurred soon after that legislation came into force. Section 24(1) of the YOA sets out conditions that must be met before custody is imposed. Originally, it applied only to secure custody committals, not to open custody committals. The provinces became concerned that youth court judges were imposing open custody in situations that did not call for a custodial sentence. In response to these provincial concerns about the open custody option "widening the net" of custody, and in an effort to reduce the use of

3y This interpretation of s. 38(3)(e) would constitute a radical departure from the way that previous findings of guilt are used in the sentencing process under the YOA. Data from 1996 to 1997 and 1998 to 1999 demonstrate that a youth's criminal record dramatically increases the likelihood of imprisonment, even for very minor offences. If a young person's record contains a finding of guilt for which he or she has already received a sentence of imprisonment, it is also more likely that he or she will be given a longer custodial sentence the next time he or she commits an offence, even if the offence is a relatively minor one (see Doob \& Sprott, supra note 2 at 264, 266; and T. Sanders, "Sentencing of Young Offenders in Canada, 1998/99" (2000) 20:7 Juristat at 6). Thus. under the YOA, it would be fair to conclude that the existence of a previous criminal record can serve to make a youth sentence disproportionately harsh.

4) In fact, s. 39 of the $Y C J A$, which states the prerequisites that must be met before a committal to custody is ordered, allows such a committal if the young person has failed to comply with noncustodial sentences. The various subsections of $s .39$ will be discussed later in the article when the topic of restraint and young offender sentencing is addressed. 
open custody, s. 24(1) of the YOA was amended so that its criteria also applied to open custody committals. ${ }^{41}$ This amendment to the YOA came into force on 1 September 1986. If the amendment had its intended effect, the use of open custody should have declined after this point. However, it is clear that this did not happen. Between 1985 and 1986, and between 1988 and 1989, open custody admissions increased by 41 percent in British Columbia and 52 percent in Ontario. ${ }^{42}$ This data, coupled with evidence that the quality and quantity of youth crime had not shown any significant increase from 1985 to $1997,{ }^{43}$ suggests that the 1986 amendment to s. 24(1) of the YOA did not constrain the use of open custody.

Ottawa then attempted to provide more specific legislative guidance to curb the use of custody for young offenders. In 1995, Parliament added s. 24(1.1) to the YOA. This section states that in determining whether or not to commit a young person to custody, the youth court shall take into account a number of factors. One of the factors, as previously discussed in this article, involves the prohibition on imposing custody in order to effect rehabilitation. The other factors in s. 24(1.1) are as follows:

(b) that a young person who commits an offence that does not involve serious personal injury should be held accountable to the victim and to society through non-custodial dispositions whenever appropriate; and

(c) that custody shall only be imposed when all available alternatives to custody that are reasonable in the circumstances have been considered.

In addition, as part of the 1995 amendments, s. 24(4) was added to the $Y O A$. It states that when youth court judges impose sentences of incarceration they must indicate why a non-custodial option would not have been appropriate.

Statistical evidence fails to reveal a decreased use of incarceration under the $Y O A$, despite the 1995 amendments to the Act. In fact, from 1992-1993 to 2000-2001, the percentage of youth court sentences involving custody remained stable, at around 34 percent. $^{44}$

Some members of the judiciary have engaged in creative interpretations of s. 24(1.1) so as to impose custodial sentences. For example, in R. v. A.J.G.N., ${ }^{45}$ the majority of the Manitoba Court of Appeal took no issue with a youth court judge sentencing a first offender who was found guilty of a number of property offences to six months in open custody and eighteen months probation. The youth court judge considered the impact

See An Act to amend the Young Offenders Act, the Criminal Code, the Penitentiary Act and the Prisons and Reformatories Act, R.S.C. 1985, c. 24 (2d Supp.).

12 A. Markwart, "Custodial Sanctions Under the Young Offenders Act" in R.R. Corrado et al., eds., Juvenile Justice in Canada (Toronto: Butterworths, 1992) 229 at 264.

1 See A.N. Doob, V. Marinos \& K.N. Varma, Youth Crime and the Youth Justice System in Canada: A Research Perspective (Toronto: Centre of Criminology, University of Toronto, 1995) at 20-26; and A.N. Doob \& J.B. Sprott, "Is the 'Quality' of Youth Violence Becoming More Serious?" (1998) 40 Can. J. Crim. 185. 
of the property crimes on the victims to have an element of personal injury so as to come within the exception in s. $24(1.1)\left(\right.$ b).$^{46}$ Other courts have chosen to focus on the phrases "whenever appropriate" and "reasonable in the circumstances" as granting them an unfettered discretion to impose custodial sentences as they see fit. ${ }^{47}$

Given this situation, it is understandable and commendable that the $Y C J A$ provides much stronger and clearer legislative direction in terms of the use of restraint in imposing custodial sentences. The preamble to the $Y C J A$ states that the youth criminal justice system should reduce the over-reliance on incarceration for non-violent young persons. Section $38(2)(e)(i)$ recognizes that youth sentences, while still having to conform to the principle of proportionality, have to be the least restrictive sentences that are consistent with the protection of the public. However, it is s. 39 of the YCJA that most constrains the use of custodial sentences:

(1) A youth justice court shall not commit a young person to custody under section 42 (youth sentences) unless

(a) the young person has committed a violent offence;

(b) the young person has failed to comply with non-custodial sentences;

(c) the young person has committed an indictable offence for which an adult would be liable to imprisonment for a term of more than two years and has a history that indicates a pattern of findings of guilt under this Act or the Young Offenders Act...; or

(d) in exceptional cases where the young person has committed an indictable offence, the aggravated circumstances of the offence are such that the imposition of a non-custodial sentence would be inconsistent with the purpose and principles set out in section 38 .

(2) If any of paragraphs (1)(a) to (c) apply, a youth justice court shall not impose a custodial sentence under section 42 (youth sentences) unless the court has considered all alternatives to custody raised at the sentencing hearing that are reasonable in the circumstances, and determined that there is not a reasonable alternative, or combination of alternatives, that is in accordance with the purpose and principles set out in section 38.

(3) In determining whether there is a reasonable alternative to custody, a youth justice court shall consider submissions relating to

(a) the alternatives to custody that are available;

(b) the likelihood that the young person will comply with a non-custodial sentence, taking into account his or her compliance with previous non-custodial sentences; and

(c) the alternatives to custody that have been used in respect of young persons for similar offences committed in similar circumstances.

(4) The previous imposition of a particular non-custodial sentence on a young person does not preclude a youth justice court from imposing the same or any other non-custodial sentence for another offence.

(9) If a youth justice court imposes a youth sentence that includes a custodial portion, the court shall state the reasons why it has determined that a non-custodial sentence is not adequate to achieve 
the purpose set out in subsection 38(1), including, if applicable, the reasons why the case is an exceptional case under paragraph (1)(d)..$^{48}$

Section 39(1)(a) arguably constitutes a reversal of decisions like A.J.G.N. While the phrase "serious personal injury" in s. 24(1.1)(b) of the YOA certainly seems to suggest restricting the use of custody to violent offences, it was accepted by at least some courts that the loss of one's property could constitute a serious personal injury. Section 39(1)(a) now specifically restricts the use of custody to violent offences. To the extent that ambiguity remains, it surrounds what is meant by the phrase "violent offence." Although the YCJA does not provide a definition for this phrase, s. 2(1) does provide a definition of "serious violent offence," which can be used to clarify the meaning of "violent offence." The definition of "serious violent offence" is an offence involving a young person causing or attempting to cause serious bodily harm. It can therefore be argued that a "violent offence" for the purposes of s. 39(1)(a) is an offence involving a young person causing or attempting to cause bodily harm.

Section 39(1)(b) also contains wording that gives clear criteria to judges in making the decision whether or not to impose a custodial sentence on a young person. The subsection states that, before a committal to custody can be ordered, the young person must have failed to comply with non-custodial sentences. Consequently, it can and has been contended that there must be at least two prior non-custodial sentences that the youth did not comply with before such a youth will be given a sentence of incarceration. ${ }^{49}$

Although the operation of s. 39(1)(c) could significantly reduce the use of youth incarceration, s. 39(1)(d) may seriously undermine the potential beneficial effects of ss. 39 (1)(a)-(c). It has been argued that the use of the words "history" and "pattern" and the plural "findings" in s. 39(1)(c) suggests that, before a young person will be deemed to come within the ambit of this subsection, he or she must have a criminal record consisting of at least three prior findings of guilt. ${ }^{50}$ Doob and Sprott have remarked on the importance of s. 39(1)(c):

[The subsection] is more important than it might appear since many of the less serious offenses, such as minor property crimes, failure to appear, or failure to comply with a probation order, carry adult penalties of two years imprisonment or less. In that way, this section may reduce the use of custody for minor repeat offenders. ${ }^{51}$

The problem, of course, is that s. 39(1)(d) provides a potential escape clause that judges could use to avoid the strictures of s. 39(1)(a)-(c). It is hoped that youth justice court

Section 39 makes extensive reference to $s .38(1)$, which reads,

(1) The purpose of sentencing under section 42 (youth sentences) is to hold a young person accountable for an offence through the imposition of just sanctions that have meaningful consequences for the young person and that promote his or her rehabilitation and reintegration into society, thereby contributing to the long-term protection of the public.

ง9 Bala, supra note 16 at 448 .

51) Ibid. at 449.

51 Supra note 2 at 266 
judges heed the opening words of s. $39(1)(d)$ and use this escape clause only in exceptional cases.

Sections 39(3)(b) and 39(4) are legislative attempts to stop the use of the step principle in determining youth sentences. The step principle encourages the use of progressively harsher sanctions for each subsequent offence an offender commits, regardless of the gravity of the offence. Construed in this fashion, the step principle is inimical to the principle of proportionality and can lead to the increased use of incarceration for relatively minor offences.

One of the largest obstacles to overcome in reducing the use of youth incarceration is judicial inertia concerning youth sentencing practices. The history and effect of legislative intervention under the $Y O A$ suggests that the force of this inertia cannot easily be discounted. Although the tight drafting of certain provisions in the $Y C J A$ significantly reduces the scope for creative judicial statutory interpretation that can be used to justify old sentencing patterns, there is the real prospect that some judges will simply choose to ignore the requirements of the new legislative regime.

An example of this practice can be seen in R. v. S.(N.L.). ${ }^{52}$ This case arose after the 1995 amendment to the $Y O A$ that specifically prohibited judges from imposing sentences of incarceration on the basis of rehabilitative concerns. In S.(N.L.), a 17-yearold female first offender pleaded guilty to two counts of robbery. Both incidents can be described as muggings that occurred on the same date. The youth court judge sentenced her to six months open custody and eighteen months probation. After citing the fact that the young offender was neglected by her mother and abused by her father, the youth court judge stated,

I recognize you have no prior record, but in light of the very sad history which you have which I am not blaming you for as it is not your fault, I can see no viable option at this point in time other than putting you into an ongoing. structured environment and that frankly for me to release you to the community at this time. as has been suggested, I think would be a dereliction of my responsibility to you... So I am going to sentence you to a period of open custody. ${ }^{53}$

The British Columbia Court of Appeal noted that the youth court judge's first and primary concern was rehabilitation and that as the sentence was one clearly designed with the young offender's best interests in mind, it dismissed the young offender's sentence appeal. Thus, the Court of Appeal acknowledged that the only reason S.(N.L.) was given a custodial sentence was for rehabilitation reasons and it upheld the sentence on this basis despite the enactment of s. $24(1.1)(a)$ of the $Y O A .^{54}$ W.D.F.L. 968 (N.S.C.A.); and R. v. P.B.G. (1997), 47 Alta. L.R. (3d) 277 (C.A.).

si $\quad$ S.(N.L.), ibid. at 248.

ss Section 24(1.1)(a) of the YOA was not mentioned by the Court of Appeal or the youth court judge in this case. It should be kept in mind that many youth court judges also do take seriously the 1995 amendments to the YOA in imposing youth sentences. See, e.g., the reasons of Steel J.A. dissenting in A.J.G.N., R. v. M.C. (1997), 115 Man. R. (2d) 217 (C.A.); and R. v. J.D.V.T. (1996), 108 C.C.C. (3d) 94 (N.S.C.A.). 
The other major impediment to reducing youth incarceration under the $Y C J A$ is government funding. Without sufficient investment by the provinces in implementing non-custodial options with punitive conditions, such as home curfews enforced by electronic monitoring devices, judges may feel forced to impose terms of incarceration even in circumstances where public safety and proportionality could countenance a sentence served in the community. ${ }^{55}$

\section{RESTORATIVE JUSTICE AND RACE}

Many provisions in the YCJA underscore the fact that Parliament wants the judiciary to seriously consider restorative processes and conditions when imposing youth sentences. For instance, s. 19 explicitly recognizes that youth justice court judges have the power to convene conferences for the purpose of giving advice on appropriate sentences to mete out. In addition, s. 3(1)(c)(ii) makes clear that, although youth sentences should encourage the repair of harm done to victims and the community, such restorative sentences must be within the limits of fair and proportionate accountability. Thus, restorative concerns cannot be the basis of a disproportionately severe sentence. Earlier in this article, the phrase "subject to" in the context of s. 38(2)(e) was argued as meaning that proportionality must be considered the guiding factor in determining youth sentences; it is not merely a limit on the severity of youth sentences from which lenient departures can be tolerated on the basis of rehabilitation. Because s. 38(2)(e) makes rehabilitative, as well as restraint and restorative justice concerns, subject to the principle of proportionality, ${ }^{56}$ these latter two concerns cannot result in disproportionately lenient youth sentences either. Consequently, although restorative justice cannot influence the severity of an otherwise proportional youth sentence, it can help to determine the form a proportional youth sentence may take. ${ }^{57}$

Some restorative justice processes, such as family group conferencing, can be partly punitive. In a typical family group conference the offender, the victim, their families, community representatives, and a mediator meet outside of the formal court process.

The YCJA does, however, create some new non-custodial sentences that have the possibility of reducing incarceration levels if the provinces allocate sufficient levels of funding so as to make them a viable choice for youth justice court judges. A prime example of such a sentence is the new deferred custody and supervision order created by s. 42(2)(p). For more information about this sentencing option, which Bala describes as a sort of conditional sentence for youths, see Bala, supra note 16 at $457-60$.

st. See ss. 38(2)(e)(i) and (iii) respectively.

57 It should be noted that there are those who question whether restorative justice principles can be reconciled with proportionality-driven sentencing schemes, or even with any type of adjudicative process. See, e.g., B.P. Archibald, "Fault, Penalty and Proportionality: Connecting Sentencing to Subjective and Objective Standards of Criminal Liability (with Ruminations on Restorative Justice)" (1998) 40 Crim. L.Q. 263. While it is undoubtedly true that some restorative justice approaches, such as family group conferencing, require processes of mediation that can sometimes be difficult to accommodate within traditional adversarial sentencing hearings, other restorative justice objectives, such as the ascertaining and enforcing of restitution, are well suited to an adjudicative setting. It is also important to remember that restorative justice has a large and explicitly recognized role to play in terms of diversion under the $Y C J A$. In this regard, see ss. 5(b), (c), (d), and 19(2) of the YCJA as well as N. Bala, "Diversion, Conferencing and Extrajudicial Measures for Adolescent Offenders" in this issue at 991. 
These individuals make representations at the meeting and, if everything goes well, a community-based settlement acceptable to all is eventually reached. The communitybased sentence that is agreed upon is then relayed to the judge who, in a formal court session, imposes the sentence. During family group conferences, offenders often listen to victims describe the harms they have suffered at the hands of the offenders, and the offenders sometimes explain their feelings about the offence and why they engaged in the offending behaviour. As noted by Wright, "Restorative justice may give the appearance of being soft, although it can be seen as more demanding than [custodial] punishment because it makes offenders face up to the real effects of their actions." $\$ 8$ There is little doubt that there is a level of onerousness involved in offenders serving periods of time in custody for their crimes. However, offenders can serve these sentences while largely denying or ignoring their responsibility to their victims and communities. The family group conferencing process and the resulting sentence to be served in the community, which may involve restitution or compensation by way of a monetary sum or personal services, make it difficult for an offender not to take seriously the effect of his or her actions on his or her victim and community.

One particular group of young people could be argued to warrant special attention as far as restorative justice is concerned under the $Y C J A$. Section 3(1)(c)(iv) states that, within the limits of proportionality, the measures that should be taken against young persons who commit offences should respect, among other things, ethnic, cultural and linguistic differences, and respond to the needs of Aboriginal young people. Given the fact that restorative justice is a movement that stems from indigenous people's wisdom about justice, ${ }^{59}$ it seems particularly appropriate to use restorative processes and conditions when crafting youth sentences for Aboriginal young people. Section 38(2)(d) of the $Y C J A$ states that "all available sanctions other than custody that are reasonable in the circumstances should be considered for all young persons, with particular attention to Aboriginal young persons." When this section is read together with ss. 38(1) and 39(3)(b), it seems to be a specific direction to youth justice court judges to use non-custodial sentences for Aboriginal young people except when the youths present too great a risk of non-compliance with community-based sentences or constitute too much of a danger to the protection of the public.

The structure and wording of s. 38 of the $Y C J A$ make for a strong argument that, while proportionality determines punishment for many young offenders, it does not determine punishment for Aboriginal young offenders. Section 38(2)(d), unlike s. 38(2)(e), has not expressly been made "subject to" s. 38(2)(c). Therefore, it could be contended that youth justice court judges, in sentencing Aboriginal young people under the $Y C J A$, cannot impose more severe sentences than the principle of proportionality would tolerate, but they can impose disproportionately lenient youth sentences on such offenders. 
The nature of the parliamentary debates concerning s. 38(2)(d) further buttress this argument. During the debates on this section, members of the official opposition repeatedly stated that their interpretation of the section was that it allows Aboriginal youths to receive less severe sentences than non-Aboriginal youths would receive even when the gravity of their crimes are similar. Members of the government, as well as of the New Democratic Party, the Progressive Conservative Party, and the Bloc Québécois did not deny that this was the correct interpretation to be given to the section, but these Members of Parliament insisted that such an amendment was needed in order to address the overrepresentation of Aboriginal young people in youth custody centres. A representative sample of the tenor of the debate illustrates the types of concerns that were raised:

Hon. Martin Cauchon (Minister of Justice and Attorney General of Canada, Lib.): It is disturbing to see such a large number of young aboriginals in detention centres... The amendment proposed by the Senate [adding s. 38(2)(d) to the $Y C J A$ ] and the new act will provide a framework that will promote a fairer justice system that will be better suited to young aboriginals' needs. We should accept this amendment and implement Bill C-7. ${ }^{60}$

Mr. Dick Proctor (Palliser, NDP): We hope that the amendment before us today will provide for greater latitude in sentencing aboriginal young offenders by allowing them to receive alternative sentences that may have more to do with restorative justice and other aboriginal principles involving their communities. ${ }^{61}$

Mr. Chuck Cadman (Surrey North, Canadian Alliance): If our goal is to achieve the equality of all people. how can we justify race specific sanctions under the criminal law? Can we reasonably expect tolerance and respect when some offenders based solely on their racial origin are singled out for less punitive sanctions than offenders of all other racial origins, all other things, including circumstances of the offence being equal? ${ }^{62}$

Mr. Gerald Keddy (South Shore, PC): [T]he inclusion of this section ... is necessary to deal with the over-representation of aboriginal [young] people in prison and to encourage sentencing judges to have recourse to a restorative approach to sentencing. ${ }^{63}$

Mr. Randy White (Langley-Abbotsford, Canadian Alliance): In the minister's words of a moment ago the legislation would allow for special consideration when sentencing aboriginals. The minister has thus confirmed it is possible, indeed probable, that offenders will get less of a sentence because they are aboriginal.... Why is the government moving in the direction where fair and firm justice would reside with non-aboriginals only? ${ }^{64}$

Hon. Martin Cauchon: Mr. Speaker, as I have said, the amendment is essentially based on one of the principles of Bill C-7. Clause 3 of Bill C-7 takes into consideration young aboriginals. The Senate amendment takes this into consideration as well as the sentencing. The exact same thing is found in 
the criminal code. This is always a very sensitive issue. We on this side of the House do believe in rehabilitation. $^{65}$

Mr. Steve Mahoney (Mississauga West, Lib): I said in my speech that the amendment would bring the bill into line with Canada's criminal code.... [T] youth break the cycle. That is what I believe the bill would do. ${ }^{66}$

Although it is a traditional rule of statutory interpretation that the legislative history of an enactment is not admissible to assist in its interpretation, ${ }^{67}$ there are indications that Canadian courts are beginning to relax and even ignore this rule when the legislative history of a provision is helpful in deciphering its meaning. ${ }^{68}$

Pursuant to s. 50 of the YCJA, s. 718.2(e) of the Criminal Code applies to the determination of youth sentences. ${ }^{69}$ This means that the jurisprudence interpreting $\mathbf{s}$. 718.2(e) will be applicable to the determination of youth sentences, and this jurisprudence also suggests that, in sentencing Aboriginal offenders, courts can give sentences that are more lenient than the principle of proportionality dictates. The Supreme Court in R. v. Gladue ${ }^{70}$ stated that s. 718.2(e) was not intended to create an automatic "Aboriginal discount" for sentencing purposes, but rather to "alter the method of analysis which sentencing judges must use in determining a fit sentence for Aboriginal offenders." 71 Yet the court also stated that when sentencing judges feel compelled, because of the violence and/or seriousness of the crime committed, to impose a term of custody on an Aboriginal person, they should consider a shorter term than the one they would impose on a non-Aboriginal offender. ${ }^{72}$ As observed by Stenning and Roberts,

is Ibid.

sw. Ibid. at 8664 .

(17 Letang v. Cooper, [1964] 2 All E.R. 929 (C.A.).

6. See, e.g., Lor-Wes Contracting v. R. (1985), [1986] I F.C. 346 (C.A.).

(19) Section 718.2(e) of the Criminal Code states that a "court that imposes a sentence shall also take into consideration the following principles ... all available sanctions other than imprisonment that are reasonable in the circumstances should be considered for all offenders, with particular attention to the circumstances of Aboriginal offenders."

70 R. v. Gladue, [1999] I S.C.R. 688 [hereinafter Gladue].

"Ibid. at para. 75. In R. v. Wells, [2000] I S.C.R. 207 at paras. 53 and 38 [hereinafter Wells], the court elaborated on what it meant by this different method of analysis:

it will be necessary in every case for the sentencing judge to take judicial notice of systemic or background factors that have contributed to the difficulties faced by aboriginal people in both the criminal justice system, and throughout society at large.

In considering the circumstances of aboriginal offenders, the sentencing judge must take into account, at the very least, both the unique systemic or background factors that are mitigating in nature in that they may have played a part in the aboriginal offender's conduct, and the types of sentencing procedures and sanctions which may be appropriate in the circumstances for the offender because of his or her particular aboriginal heritage or connection.... In particular, given that most traditional aboriginal approaches place a primary emphasis on the goal of restorative justice, the alternative of community-based sanctions must be explored. 
Changing the methodology of sentencing in this way will inevitably change the dispositional pattern. Despite the Court's rationalizations to the contrary, the practical effect of this alternate methodology is predictable: the sentencing of an Aboriginal offender is less likely to result in a term of custody and, if custody is imposed, it is likely to be shorter in some cases than it would have been had the offender been non-Aboriginal. ${ }^{73}$

The wisdom of adopting a proportionally-driven sentencing scheme for nonAboriginal young people and a proportionally-limited sentencing structure for Aboriginal young people is a matter of much debate. There are those who question whether Aboriginal overrepresentation in custodial institutions has anything to do with sentencing practices or can be effectively dealt with by sentencing practices. ${ }^{74}$ Others, although not seeing the problem of Aboriginal overrepresentation as emanating from discriminatory disparities in the sentencing of Aboriginal offenders, contend that sentencing reform can be used as one of many remedies for Aboriginal overrepresentation in custodial institutions. ${ }^{75}$ On the one hand, there are those who are concerned that formal equality among offenders is breached by not having proportionality determine sentencing for all offenders. ${ }^{76}$ On the other hand, some people are more troubled at the prospect of substantive equality being impinged when Aboriginal offenders, who suffer from a legacy of colonialism that other offenders have not experienced, are sentenced as severely as non-Aboriginal offenders. ${ }^{n}$

\section{Conclusion}

Whether youth sentencing patterns will really change under the new juvenile justice legislative regime is still very much in the hands of the judiciary. If youth justice court judges are not educated about the $Y C J A$ 's provisions, they may simply continue the sentencing practices that they engaged in under the $Y O A{ }^{78}$ To overcome judicial ignorance or inertia, appellate courts must intervene and ensure that judges take seriously the fact that sentencing under the $Y C J A$ is meant to be different from under the $Y O A$.

Even if the judiciary is willing and able to change its youth sentencing practices, another potential obstacle to effecting youth sentencing reform could be erected by governments. If provincial governments do not invest in non-custodial sentencing options, particularly those with punitive elements, judges may feel forced to impose

P. Stenning \& J.V. Roberts, "Empty Promises: Parliament, The Supreme Court, and the Sentencing of Aboriginal Offenders" (2001) 64 Sask. L. Rev. 137 at 162.

See, e.g., ibid. and J.-P. Brodeur, "On the Sentencing of Aboriginal Offenders: A Reaction to Stenning and Roberts" (2002) 65 Sask. L. Rev. 45.

See, e.g., J. Rudin \& K. Roach, "Broken Promises: A Response to Stenning and Roberts' 'Empty Promises"” (2002) 65 Sask. L. Rev. 3; D. Daubney, "Nine Words: A Response to 'Empty Promises: Parliament, the Supreme Court, and the Sentencing of Aboriginal Offenders"' (2002) 65 Sask. L. Rev. 35; and M. Carter, "Of Faimess and Faulkner" (2002) 65 Sask. L. Rev. 63. See Stenning \& Roberts, supra note 73.

See Rudin \& Roach, supra note 75.

Positive developments in this respect are the judicial training on the $Y C J A$ provided by the National Judicial Institute in Toronto in September 2002 and the judicial education seminars for Alberta provincial court judges scheduled to be held in Calgary and Edmonton in March 2003. 
high numbers of custodial sentences on youths in order to comply with the principle of proportionality.

A troubling fact in this regard is the current level of federal-provincial cost sharing in the youth justice field. The federal government did reimburse the provinces for 50 percent of the programs and services that needed to be established or expanded as a result of the enactment of the YOA. But federal funding was frozen in 1989. Consequently, the overall federal share of eligible provincial costs with respect to youth justice has fallen to approximately 30 percent. ${ }^{79}$ When the $Y C J A$ was first introduced into the House of Commons, the federal government announced that it would transfer an extra $\$ 400$ million over five to six years to the provinces to help implement the new youth justice regime ${ }^{80}$ These increased transfer payments still amount to less than half the cost of programming for the youth justice system. As a result, it seems likely that the only way that new non-custodial sentencing options will become available is if the provincial governments agree to pay for most of the costs associated with them. Given the current political climate in Canada, with the public simultaneously calling for deficit reduction, lower taxes, and increased government spending on health and education, the prospect of the provinces outlaying significant new funds for new non-custodial youth sentencing options seems remote, especially in the absence of a pledge of 50-50 costsharing by the federal government.

There is little doubt that the $Y C J A$ provides much clearer legislative direction to judges on how to approach the youth sentencing enterprise than does the YOA. However, it is also readily apparent that if Ottawa truly wants to change the face of youth sentencing, it must do more than simply pass a statute. 